\title{
A Two Cascaded Boost Converter with High Voltage Gain Module
}

\author{
Muhammad Zeeshan Malik ${ }^{1 *}$, Amjad Ali ${ }^{1,2}$, Dileep Kumar ${ }^{3}$ \\ ${ }^{1}$ College of Electrical Engineering, Zhejiang University, Hangzhou, China. \\ ${ }^{2}$ Faculty of Engineering Sciences and Technology (FEST), Hamdard University, Karachi 74600, Pakistan. \\ ${ }^{3}$ College of Control Science and Engineering, Zhejiang University, Hangzhou 310027, China. \\ * Corresponding author. Tel.: 0092-300-6330583; email: malik4one@yahoo.com \\ Manuscript submitted June 30, 2017; accepted August 18, 2017.
}

doi: 10.17706/ijcee.2017.9.2.476-483

\begin{abstract}
In this article a new topology of cascaded boost converter with voltage multiplier cell (VMC) is presented. The proposed cascaded boost converter consist two boost converters connected in series with voltage multiplier cell. The advantage of proposed topology can attain high voltage gain without working extremely duty ratio. To validate the performance of proposed converter experimental results attain in laboratory, where input voltage 10VDC are given and the 100V output voltage attain at the duty ration $60 \%$. As compare to traditional boost converter the output voltage at same parameters is $25 \mathrm{~V}$ which is lower than the proposed converter. Voltage stress across the switches of proposed converter is less then output voltage but the voltage stress of traditional boost converter is equal to output voltage. Furthermore the voltage conversion ratio graph of proposed and conventional converters at different duty cycle and efficiency graph of proposed converter shown in experimental results respectively.
\end{abstract}

Key words: Boost converter, voltage multiplier cell, voltage stress, and high voltage gain.

\section{Introduction}

Renewable energy technologies (RETs), such as photovoltaic (PV) or fuel cell (FC) system becoming more and more popular because these systems are polluted free method to fulfill electricity requirement [1]-[4]. But the photovoltaic system has low voltage at the output; in this scenario dc-dc boost converter become very necessary part to get high voltage gain. In literature many types of boost converter presented and implemented successfully [5]. In [6] boost converter with extended cell is presented, the disadvantage of this converter has many switch which cause switching losses, which impact on overall efficiency and voltage gain not much high. In [7], [8] boost converter with voltage lift cell and switched-capacitor technics is presented respectively, the main disadvantage of these types of converter semiconductor switches surface has high transit current which cause increase the conduction losses. In [9]-[11] boost converter with coupled inductors are discussed, the disadvantage of these kind boost converter is complex because to adjust turn ratio of coupled inductor and voltage stress across the switches is equal to output voltage. In [12], [13] boost converter with transformer is presented these types of converter can get high voltage gain at the output, however the main disadvantage of transformer increase the cost, size and losses. Conventional quadratic boost converter is presented in [14], however the disadvantage of conventional converter is the voltage stress across the semiconductor switch is equal to output voltage.

Conventional boost converter depicted in Fig. 1 often use in photovoltaic system to get step-up ratio, but 
the disadvantage of conventional boost converter to get high voltage gain, need to operate at high duty ratio which cause switching losses and decrease overall efficiency because of switch need to ON for long time and the voltage stress across the switch is equal to output voltage. The voltage gain and voltage stress equation across the switch of conventional boost converter is shown below in equation (1).

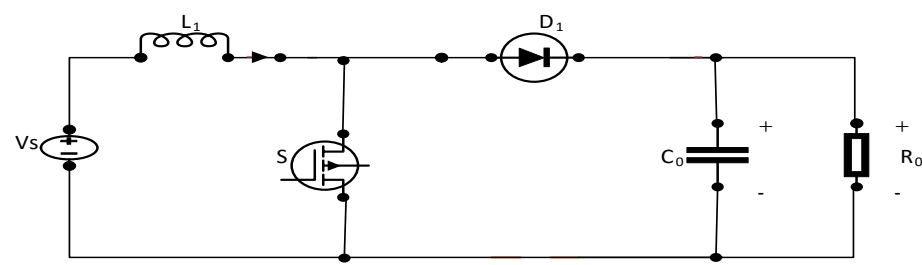

Fig. 1. Traditional boost converter.

$$
\begin{aligned}
& \mathrm{M}=\frac{\mathrm{V}_{0}}{\mathrm{~V}_{\mathrm{s}}}=\frac{1}{1-\mathrm{D}} \\
& \mathrm{V}_{\mathrm{s} \text {-stress }}=\mathrm{V}_{0}
\end{aligned}
$$

To overcome above mentioned problem a new topology of cascaded boost converter with high voltage gain module depicted in Fig. 2. The proposed converter can get high voltage gain at the output without working at extremely duty ratio and the voltage stress across the switches is lower than output voltage.

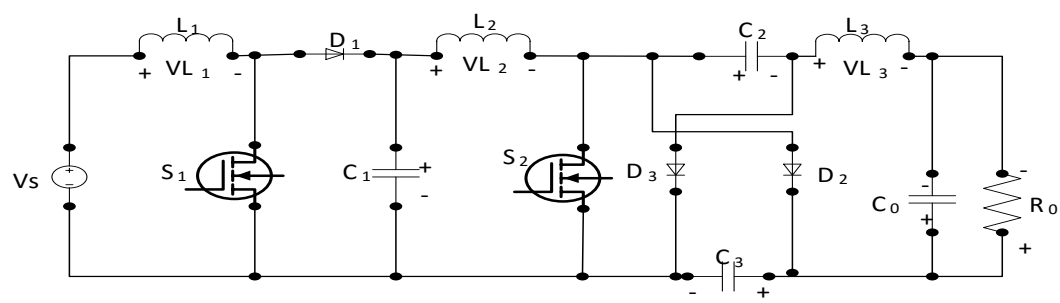

Fig. 2. Proposed converter.

\section{Operating Principle of Proposed Converter}

The switching state of proposed converter is depicted Fig. 3 (a \& b). The proposed converter has two switching state with one PWM signal. The switches $S_{1}$ and $S_{2}$ turn ON and OFF at same time. In Fig. 4 steady state waveform of proposed converter is depicted.

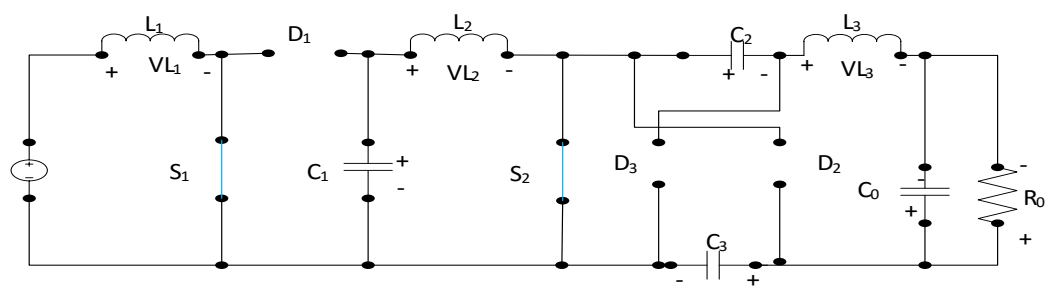

(a)

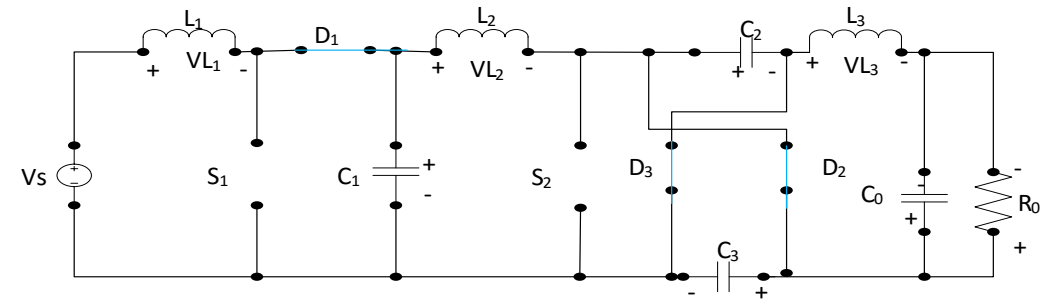

(b)

Fig. 3. Switching state of proposed converter. 


\section{State-I}

In state-I depicted Fig. 3 (a) when semiconductor switches $S_{1}$ and $S_{2}$ is $O N$, diode's $D_{1}, D_{2}$ and $D_{3}$ are revers biased. Inductors $L_{1}$ charge by supply voltage, inductor $L_{2}$ charge by capacitor $C_{1}$ voltage, at this time capacitor $C_{2}$ and $C_{3}$ work in series resultant voltage $C_{2}+C_{3}=2 V_{c 2}$ charge to inductor $L_{3}$. At this state all inductors current increase linearly. The inductors equation in this state is given below in equation (2).

$$
\begin{aligned}
& V_{L 1}=V_{S} \\
& V_{L 2}=V_{C 1} \\
& V_{L 3}=2 V_{C 2}-V_{0}
\end{aligned}
$$

\section{State-II}

In state-II depicted Fig. 3 (b) when both switches $S_{1}$ and $S_{2}$ is turn OFF, diodes $D_{1}, D_{2}$ and $D_{3}$, work in forward biased. All inductors $\mathrm{L}_{1}, \mathrm{~L}_{2}, \mathrm{~L}_{3}$ discharge stored voltage to load and there currents decease linearly. The inductors equation in this state shown below in equation (3).

$$
\begin{aligned}
& V_{L 1}=V_{S}-V_{C 1} \\
& V_{L 2}=V_{C 1}-V_{C 2} \\
& V_{L 3}=V_{C 2}-V_{0}
\end{aligned}
$$

Table 1. Components List of Converter

\begin{tabular}{ccc}
\hline Name of parameter & Symbol & Value \\
\hline Input Voltage & $\mathrm{V}_{\mathrm{S}}$ & $10 \mathrm{VDC}$ \\
Output Voltage & $\mathrm{V}_{0}$ & $100 \mathrm{VDC}$ \\
Load Resistance & $\mathrm{RL}$ & $400 \Omega$ \\
Frequency & $\mathrm{F}_{\mathrm{S}}$ & $100 \mathrm{kHz}$ \\
Inductor's & $\mathrm{L}$ & $200 \mathrm{uH}$ \\
Capacitor's & $\mathrm{C}_{1}, \mathrm{C}_{2}, \mathrm{C}_{3}, \mathrm{C}_{0}$ & $10 \mathrm{uF}$ \\
Duty cycle & $\mathrm{D}$ & 0.6 \\
\hline
\end{tabular}

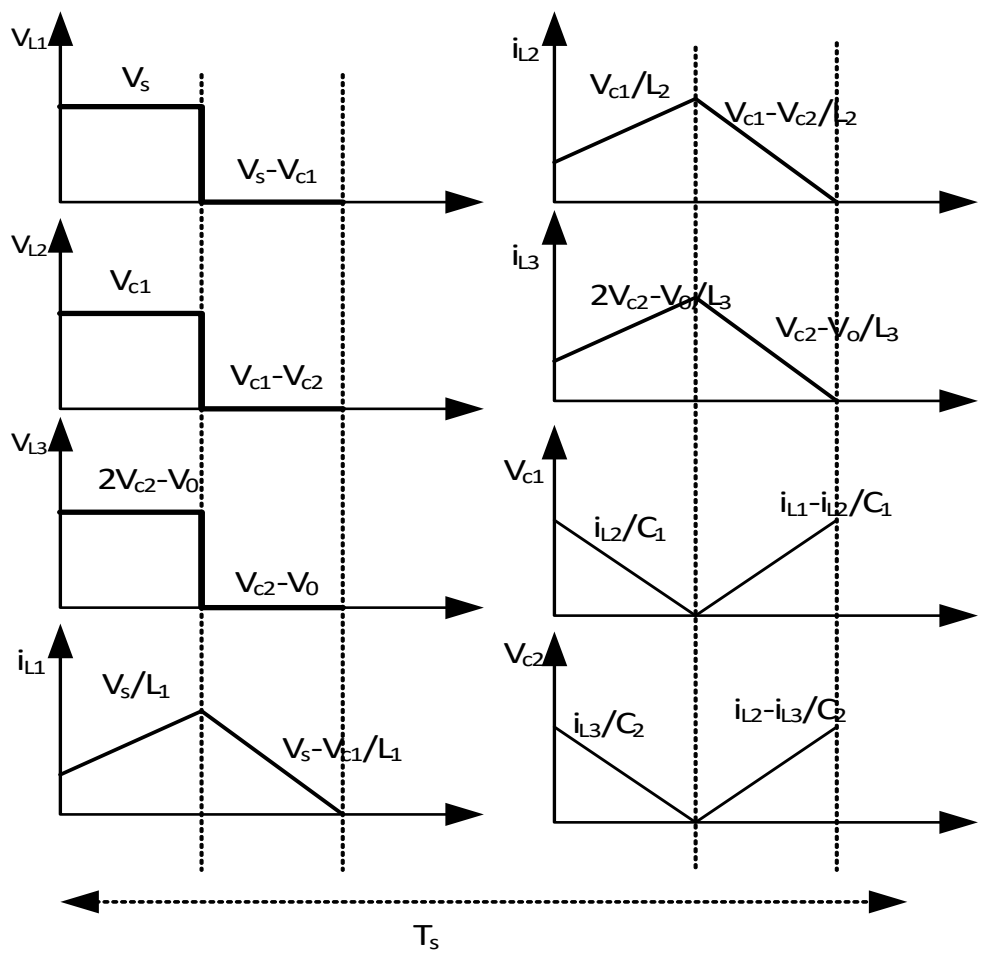

Fig. 4. Steady state waveform of proposed converter. 


\section{DC Conversion Ratio of Proposed Converter}

Using the inductor volt second balance (VSB) at $\mathrm{L}_{1}$ we get,

$$
D\left(V_{s}\right)+(1-D)\left(V_{s}-V_{c 1}\right)
$$

After solving equation (4) we get,

$$
V_{c 1}=\frac{V_{s}}{1-D}
$$

Applying (VSB) at inductor $\mathrm{L}_{2}$ we get,

$$
D\left(V_{c 1}\right)+(1-D)\left(V_{c 1}-V_{c 2}\right)
$$

After solving equation (7) we get,

$$
V_{c 2}=\frac{V_{c 1}}{1-D}
$$

In equation (7) put value of $\mathrm{Vc}_{1}$ we get,

$$
\begin{gathered}
V_{c 2}=\frac{V_{s}}{(1-D)^{2}} \\
V_{S}=V_{c 2}(1-D)^{2}
\end{gathered}
$$

Applying (VSB) at inductor $\mathrm{L}_{3}$ we get,

$$
D\left(2 V_{c 2}-V_{0}\right)+(1-D)\left(V_{c 2}-V_{0}\right)
$$

After solving equation we get,

$$
V_{0}=V_{c 2}(1+D)
$$

The voltage gain of proposed converter is,

$$
M=\frac{V_{0}}{V_{s}}=\frac{(1+D)}{(1-D)^{2}}
$$

Voltage stress across the switches,

$$
\begin{aligned}
& V_{\text {s1-stress }}=V_{c 1} \\
& V_{\text {s2-stress }}=V_{c 2}
\end{aligned}
$$

\section{Experimental Results and Discussions}

Using parameters according to Table 1 the experimental results of proposed converter carried out in laboratory depicted in Fig. 5. Fig. 5 (a) PWM signal of semiconductor switches $S_{1}$ and $S_{2}$ is depicted. In Fig. 5(b) shown input voltage where we can see is 10VDC. Fig. 5(c) shows the output voltage of proposed 
converter where we can see the output voltage is very near according to voltage gain equation (12) which is 97V. Thus, from output voltage of proposed converter it's proving that the proposed converter can get high voltage gain without working at extremely duty cycle. According to equation (1) at same parameters the output voltage of conventional converter is $25 \mathrm{~V}$ which is very low. Fig. 5 (d \& e) showed the capacitors voltage of $\mathrm{V}_{c 1}$ and $\mathrm{V}_{\mathrm{c} 2}$ respectively, which is very near 25 volt and $62.5 \mathrm{~V}$ according to equation (5 \& 7). Fig. 5 ( $\mathrm{f} \& \mathrm{~g}$ ) depicted, where we can see the voltage stress across the switches of proposed converter is $25 \mathrm{~V}$ and $62.5 \mathrm{~V}$ respectively, which is very clear voltage stress across the switches, is lower than the output voltage. According to the equation (1) the voltage stress in conventional boost converter is equal to the output voltage, thus it is prove that the proposed topology has high voltage gain with low switching stress. Fig. 6 shows the voltage conversion graph of proposed and conventional converters at different duty cycle. In voltage conversion graph it is very clear that the performance of proposed converter at different duty cycle is batter then conventional boost converter.
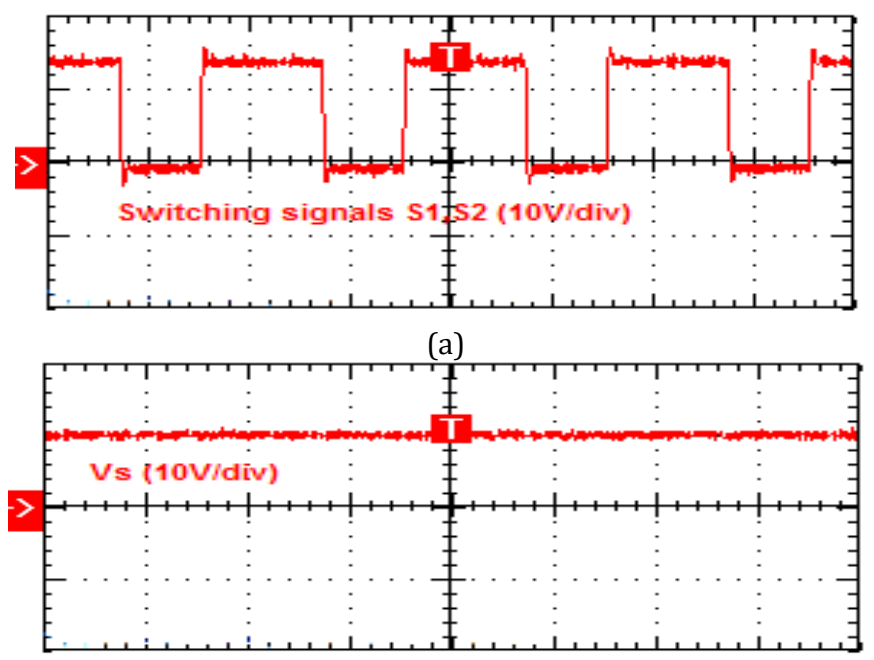

(b)

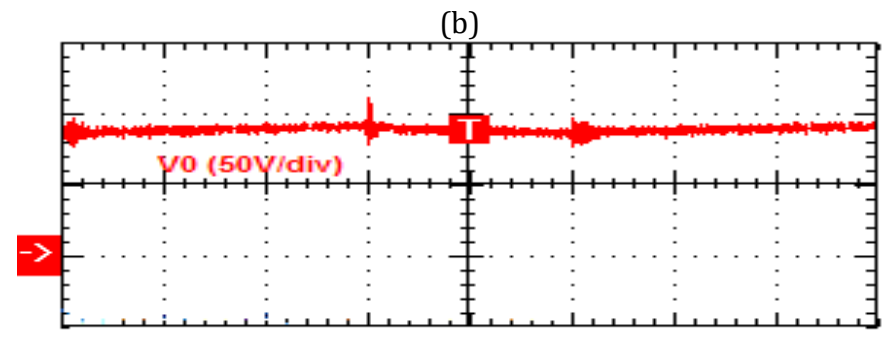

(c)

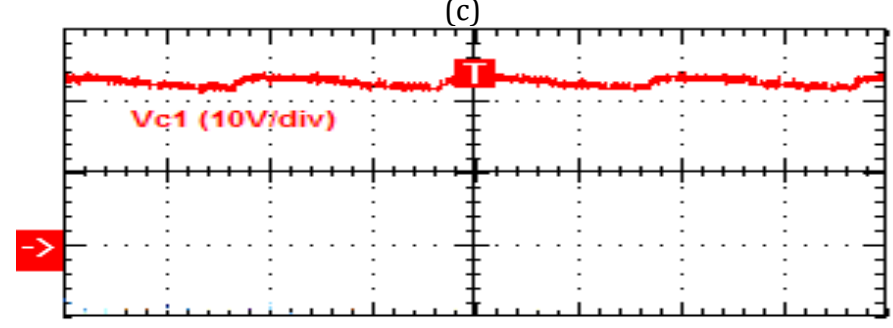

(d)

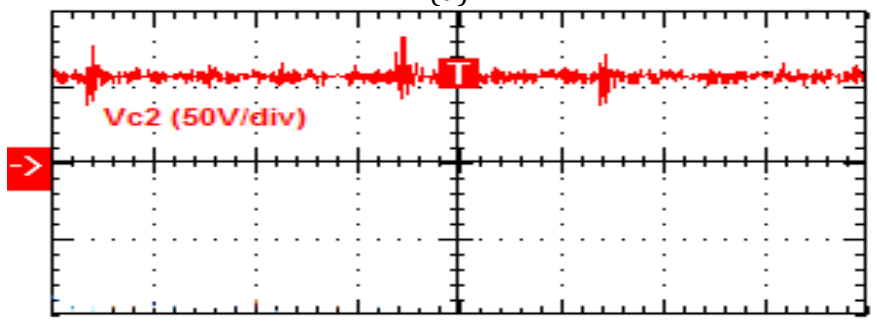

(e) 

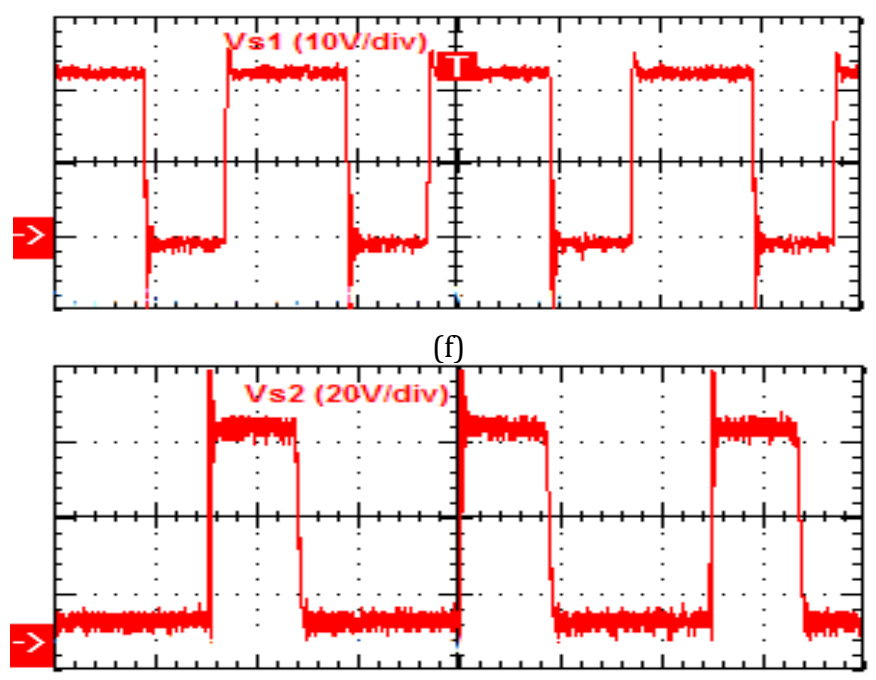

(g)

Fig. 5. Experimental results of proposed converter.

In Fig. 7 shows the efficiency of proposed converter where we can clearly see the maximum efficiency $96 \%$ achieve at input power $203 \mathrm{~W}$ and minimum efficiency $88 \%$ achieve at input power $37 \mathrm{~W}$.

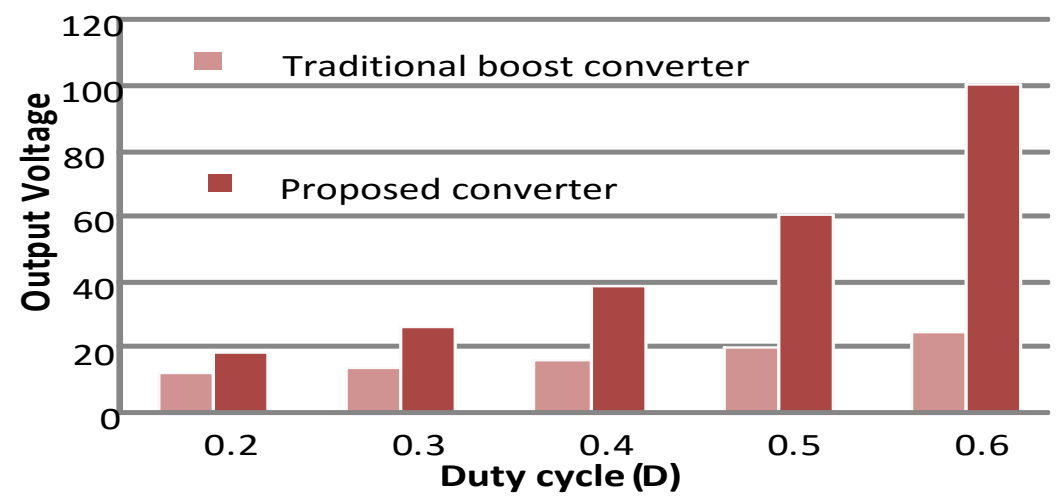

Fig. 6. Voltage conversion ratio.

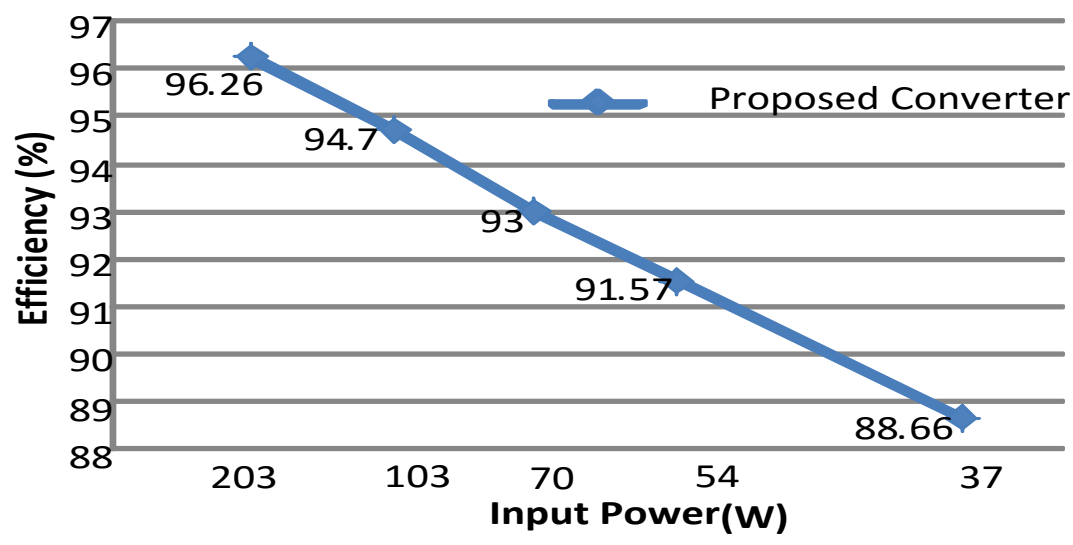

Fig. 7. Efficiency graph of proposed converter.

\section{Conclusion}

In this article a new topology of cascaded boost converter with high voltage gain module is presented. Furthermore, the theoretical analyze and experimental results are given and discuss in details. From theoretical and experimental results it is prove that the performance of proposed topology is much better 
than conventional boost converter. The proposed converter is very useful in renewables energy system where we need low input to high step-up ratio such as photovoltaic (PV) and fuel cell (FC) systems.

\section{References}

[1] Ali, A., Farooq, A., Muhammad, Z., Habib, F., \& Malik, S. A. (2015). A review: DC microgrid control and energy management system. Energy Sources (RES), 7, 10,

[2] Farooq, A., Malik, Z., Qu, D., Sun, Z., \& Chen, G. (2015). A three-phase interleaved floating output boost converter. Advances in Materials Science and Engineering, 2015.

[3] Farooq, A., Malik, Z., Sun, Z., \& Chen, G. (2015). A Review of non-isolated high step-down Dc-Dc Converters. International Journal of Smart Home, 9, 133-150.

[4] Garcia, F., Pomilio, J., \& Spiazzi, G. (2012). Comparison of non-insulated, high-gain, high-power, step-up DC-DC converters. Proceedings of the 2012 Twenty-Seventh Annual IEEE, Applied Power Electronics Conference and Exposition (APEC) (pp. 1343-1347).

[5] Hosseini, S., Babaei, E., \& Nouri, T. (2014). An interleaved high step-up DC-DC converter with reduced voltage stress across semiconductors. Proceedings of the 2014 IEEE 27th Canadian Conference on Electrical and Computer Engineering (CCECE) (pp. 1-6).

[6] Malik, M. Z., Ali, A., Xu, Q., \& Chen, G. (2016). A new quadratic boost converter with voltage multiplier cell: An analysis and assessment. International Journal of Smart Home, 10, 281-294.

[7] Malik, M. Z., Farooq, A., Ali, A., \& Chen, G. (2016). A DC-DC boost converter with extended voltage gain. Proceedings of the MATEC Web of Conferences.

[8] Malik, M. Z., Xu, Q., Farooq, A., \& Chen, G. (2017). A new modified quadratic boost converter with high voltage gain. IEICE Electronics Express, 14, 20161176-20161176.

[9] Newlin, D. J. S., Ramalakshmi, R., \& Rajasekaran, S. (2013). A performance comparison of interleaved boost converter and conventional boost converter for renewable energy application. Proceedings of the 2013 IEEE International Conference on Green High Performance Computing (ICGHPC) (pp. 1-6).

[10] Qian, W., Cao, D., Cintron-Rivera, J. G., Gebben, M., Wey, D., \& Peng, F. Z. (2012). A switched-capacitor DC-DC converter with high voltage gain and reduced component rating and count. IEEE Transactions on Industry Applications, 48, 1397-1406.

[11] Thounthong, P. (2012). Control of a three-level boost converter based on a differential flatness approach for fuel cell vehicle applications. IEEE Transactions on Vehicular Technology, 61, 1467-1472.

[12] Walker, G. R. (2000). Evaluating MPPT converter topologies using a MATLAB PV model. AUPEC 2000: Innovation for Secure Power, 1, 138-143.

[13] Ye Y. M., \& Cheng, K. W. E. (2013). Quadratic boost converter with low buffer capacitor stress. IET Power Electronics, 7, 1162-1170.

[14] Zhao, Y., Li, W., Deng, Y., \& He, X. (2011). Analysis, design, and experimentation of an isolated ZVT boost converter with coupled inductors. IEEE Transactions on Power Electronics, 26, 541-550.

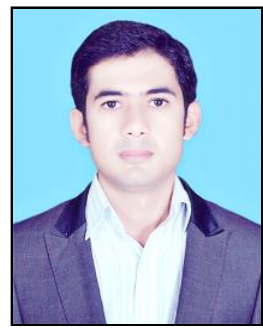

Muhammad Zeeshan Malik got his master degree in electrical engineering from Chongqing University China in 2012. In 2013 he joined the Electrical Engineering Department of Zhejiang University as a Ph.D Scholar. His research interests in the area of power electronics, power system, renewable energy technologies etc. In March 2017 he is graduated. 


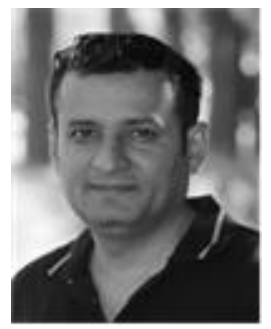

Amjad Ali is an associate professor in Hamdard University, Karachi (MIET, IEEE ); He received his M.Sc. degree in electronics from University of Sindh Jamshoro Pakistan, Got $\mathrm{Ph} . \mathrm{D}$. degree in electrical engineering from College of Electrical Engineering, Zhejiang University, Hangzhou. His research interests include renewable energy technologies, micro grid control and energy management \& energy efficiency.

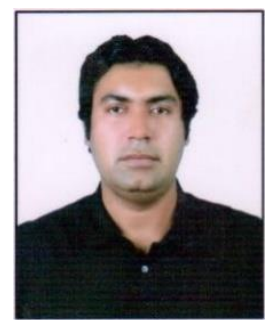

Dileep Kumar is an assistant professor in University College of Engineering \& Technology, Islamia University of Bahawalpur, Punjab, Pakistan; received his B.E. degree from Mehran University of Engineering \& Technology Jamshoro, Pakistan in 2004 and got the M.E. degree from Mehran University of Engineering \& Technology Jamshoro, Pakistan in 2006. He is currently a Ph.D scholar in College of Control Science \& Engineering Zhejiang University, Hangzhou, China. His current research interest's under water acoustic signal features analysis, artificial neural networks, finite field and its applications, etc. 